\title{
Evaluation of Humic Fertilizers Applied at Full and Reduced Nitrogen Rates on Kentucky Bluegrass Quality and Soil Health
}

\author{
Alex J. Lindsey ${ }^{1, *(D)}$, Adam W. Thoms ${ }^{1}\left(\mathbb{D}\right.$, Marshall D. McDaniel $^{2} \mathbb{D}$ and Nick E. Christians ${ }^{1}$ \\ 1 Department of Horticulture, Iowa State University, Ames, IA 50011, USA; athoms@iastate.edu (A.W.T.); \\ nchris@iastate.edu (N.E.C.) \\ 2 Department of Agronomy, Iowa State University, Ames, IA 50011, USA; marsh@iastate.edu \\ * Correspondence: alexlind@iastate.edu
}

Citation: Lindsey, A.J.; Thoms, A.W.; McDaniel, M.D.; Christians, N.E. Evaluation of Humic Fertilizers Applied at Full and Reduced Nitrogen Rates on Kentucky Bluegrass Quality and Soil Health. Agronomy 2021, 11, 395.

https://doi.org/10.3390/ agronomy11020395

Academic Editor: Masoud Hashemi

Received: 3 February 2021

Accepted: 18 February 2021

Published: 23 February 2021

Publisher's Note: MDPI stays neutral with regard to jurisdictional claims in published maps and institutional affiliations.

Copyright: (c) 2021 by the authors. Licensee MDPI, Basel, Switzerland. This article is an open access article distributed under the terms and conditions of the Creative Commons Attribution (CC BY) license (https:/ / creativecommons.org/licenses/by/ $4.0 /)$.

\begin{abstract}
Soil health and sustainable management practices have garnered much interest within the turfgrass industry. Among the many practices that enhance soil health and sustainability are applying soil additives to enhance soil biological activity and reducing nitrogen $(\mathrm{N})$ inputs-complimentary practices. A two-year study was conducted to investigate if reduced $\mathrm{N}$ fertilizer rates applied with humic substances could provide comparable turfgrass quality as full $\mathrm{N}$ rates, and whether humic fertilizers would increase biological aspects of soil health (i.e., microbial biomass and activity). Treatments included synthetic fertilizer with black gypsum (SFBG), poly-coated humic-coated urea (PCHCU; two rates), urea + humic dispersing granules (HDG; two rates), urea, stabilized nitrogen, HDG, and a nontreated control. Reduced rates of $\mathrm{N}$ with humic substances maintained turfgrass quality and cover, and reduced clipping biomass compared to full $\mathrm{N}$ rates. There were no differences in soil physical and chemical properties besides soil sulfur (S) concentration. SFBG resulted in the highest soil S concentration. Fertilizer treatments had minimal effect on microbial biomass and other plant-available nutrients. However, PCHCU (full rate) increased potentially mineralizable carbon (PMC) and N (PMN) by 68\% and 59\%, respectively, compared to the nontreated control. Meanwhile SFBG and stabilized nitrogen also increased PMC and PMN by $77 \%$ and $50 \%$, and $65 \%$ and $59 \%$, respectively. Overall, applications of reduced $\mathrm{N}$ fertilizer rates with the addition of humic substances could be incorporated into a more sustainable and environmentally friendly turfgrass fertilizer program.
\end{abstract}

Keywords: turfgrass; Poa pratensis; microbial activity; microbial biomass; potentially mineralizable carbon; potentially mineralizable nitrogen; soil additives

\section{Introduction}

Increasing interest in soil health has led to greater appreciation of soils as a vital resource key to productivity, human health, and sustainability [1]. Doran [1] defines soil health (or quality) as the capacity of a living soil to function, within natural or managed ecosystems, to sustain productivity, maintain or enhance water and air quality, and promote biological health. Soil health incorporates physical, chemical, and biological indicators as well as emergent processes and properties [2]. Physical indicators include soil texture, aggregation, moisture, porosity, bulk density, and compaction [3,4]. Chemical indicators include soil carbon (C) and nitrogen (N), nutrient analysis, organic matter (SOM), pH, and cation exchange capacity (CEC) [3,4]. Physical and chemical soil properties generally have a slow response to management changes, which can make it more difficult to detect changes after changes in soil management [2,5]. Soil biological properties are often more sensitive to management practices and can reflect nutrient cycling and $C$ sequestration $[3,5,6]$. Common biological soil health indicators include microbial biomass $C(\mathrm{MBC})$ and $\mathrm{N}(\mathrm{MBN})$, soil respiration, $\mathrm{N}$ mineralization, and soil enzymes [3-5].

Soil respiration, which can be measured by the flush of $\mathrm{CO}_{2}$ following the rewetting of dried soil during a soil incubation, sometimes also called potentially mineralizable $\mathrm{C}$ 
(PMC). This measurement is an integrated indicator of soil microbial activity, pool of labile soil organic matter, and relates to crop N needs [7-9]. Potentially mineralizable N (PMN) is the inorganic net $\mathrm{N}$ released during an incubation and can be measured in tandem with PMC incubation $[8,10,11]$.

Humic substances are heterogeneous and complex mixtures of materials formed by biochemical and chemical reactions during the decay and transformation of plant and microbial remains by a process called humification [12]. In the soil, humic substances are synthesis products of phenolic substances that polymerize [13]. In general, humic substances are commonly derived from leonardite in an alkaline extraction and then further separated into humic acid and fulvic acid by acidification [14]. Humic dispersing granules (HDG; The Andersons, Inc., Maumee, OH, USA) are humic substances that contain humic acid, fulvic acid, humin, and humic acid precursor [15]. Humic substances' mode-of-action has been speculated as hormone-like or auxin-like activity [16,17]. Humic substances have been reported to effect respiration and photosynthesis, root growth promotion and branching, activation of nutrient uptake, increase nutrient use efficiency, and abiotic stress tolerance [16-19].

Earlier research has explored the benefits of humic substances on turfgrass and soil health (quality) (Table 1). The numerous benefits of humic substances application on turfgrass suggest that maintaining turfgrass quality while reducing fertilizers inputs is possible by incorporating humic substances. Humic products also claim numerous benefits to turfgrass and soil health, which include improved stress tolerances, increased nutrient availability and efficiency, improved soil structure and water holding capacity, increased effectiveness of fertilizers, and enhanced microbial activity [20,21]. These claims are largely anecdotal except for those in Table 1; however, to promote broader grower adoption will require further investigation.

The objectives of this field-based experiment were to (1) determine if the addition of humic products to fertilizers allows for a reduced $\mathrm{N}$ fertilizer rates while maintaining turfgrass quality, and (2) evaluate the impact of humic fertilizers on biological soil health (microbial biomass and activity). First, we hypothesize that adding humic products incorporated with $\mathrm{N}$ fertilizer will enhance turfgrass efficiency, thus allowing for lower $\mathrm{N}$ rates to maintain similar quality. This may be due to enhanced root growth, and/or microbial stimulation with efficient cycling of $\mathrm{N}$ with added $\mathrm{C}$ source from humic products [22-24]. Second, we hypothesize that this added C source with humic-treated $\mathrm{N}$ fertilizer products will increase microbial biomass, labile supply of $\mathrm{C}$ and $\mathrm{N}$, and general activity. $\mathrm{N}$ fertilizer alone, without balanced $C$, has been shown to decrease microbial biomass and activity [25-27].

Table 1. Benefits of humic substances on turfgrass plant and soil health (quality).

\begin{tabular}{|c|c|c|}
\hline Turfgrass & Average Increase (\%) Compared to Nontreated Control & Reference \\
\hline $\begin{array}{l}\text { Creeping bentgrass } \\
\text { (Agrostis stolonifera L.) }\end{array}$ & $15 \%$ maximum root length & [28] \\
\hline Creeping bentgrass & $\begin{array}{l}11 \% \text { photosynthetic rate, } 51 \% \text { root dehydrogenase activity, } \\
\qquad 8 \% \text { root mass }\end{array}$ & [29] \\
\hline Creeping bentgrass & $\begin{array}{l}41 \% \text { root mass, } 117 \% \alpha \text {-tocopherol (antioxidant), } \\
37 \% \text { ascorbic acid (antioxidant) }\end{array}$ & {$[30]$} \\
\hline Creeping bentgrass & $\begin{array}{c}55 \% \text { superoxide dismutase activity (antioxidant), } 6 \% \text { photochemical } \\
\text { activity, } 115 \% \text { root mass, } 7 \% \text { leaf color }\end{array}$ & [31] \\
\hline Creeping bentgrass & $114 \%$ superoxide dismutase activity, $15 \%$ photochemical activity & [32] \\
\hline Creeping bentgrass & $47 \%$ superoxide dismutase activity, $5 \%$ photochemical efficiency & [33] \\
\hline Creeping bentgrass & $11 \%$ turfgrass quality, $38 \%$ root mass, $67 \% \alpha$-tocopherol & [34] \\
\hline
\end{tabular}


Table 1. Cont.

\begin{tabular}{|c|c|c|}
\hline Turfgrass & Average Increase (\%) Compared to Nontreated Control & Reference \\
\hline Creeping bentgrass & $16 \%$ root mass & [35] \\
\hline Creeping bentgrass & $21 \%$ root length & [36] \\
\hline $\begin{array}{c}\text { Tall Fescue } \\
\text { (Schedonorus arundinaceus (Schreb.) } \\
\text { Dumort.; syn. Festuca arundinacea Scherb.) }\end{array}$ & $57 \%$ root mass, $78 \% \alpha$-tocopherol, $39 \%$ ascorbic acid & [30] \\
\hline Tall Fescue & $9 \%$ photochemical efficiency, $5 \%$ heat tolerance, $21 \%$ root strength & [37] \\
\hline $\begin{array}{l}\text { Perennial ryegrass } \\
\text { (Lolium perenne L.) }\end{array}$ & $8 \%$ total chlorophyll, $9 \%$ root length & [38] \\
\hline Perennial ryegrass & $4 \%$ turfgrass quality, $10 \%$ shoot length & [39] \\
\hline $\begin{array}{l}\text { Kentucky bluegrass } \\
\text { (Poa pratensis L.) }\end{array}$ & $19 \%$ shoot mass, $60 \%$ root mass, $38 \% \alpha$-tocopherol, $25 \%$ ascorbic acid & [40] \\
\hline Kentucky bluegrass & $14 \%$ photochemical efficiency, $36 \%$ heat tolerance, $22 \%$ root strength & [41] \\
\hline Kentucky bluegrass & $54 \%$ root mass & [42] \\
\hline Kentucky bluegrass & $\begin{array}{l}21 \% \text { turfgrass quality, } 16 \% \text { normalized vegetation index (NDVI), } \\
\qquad 11 \% \text { microbial biomass carbon }\end{array}$ & [43] \\
\hline Kentucky bluegrass & $87 \%$ total root length, $91 \%$ root surface area, $94 \%$ root volume & [22] \\
\hline $\begin{array}{c}\text { Bermudagrass } \\
\text { (Cynodon dactylon (L.) Pers.) }\end{array}$ & $87 \%$ longest root & [22] \\
\hline
\end{tabular}

\section{Materials and Methods}

\subsection{Site Description and Plot Maintenance}

A two-year experiment was initiated on 15 April 2019 at the Iowa State University Horticulture Research Station (Ames, IA, USA). In both years, the experiment was conducted on a native soil Kentucky bluegrass (KBG; Poa pratensis L.). The native soil at the experimental site is classified as a Webster clay loam (Fine-loamy, mixed, superactive, mesic Typic Endoaquolls). The soil texture was $27 \%$ sand, $39 \%$ silt, and $34 \%$ clay. The 50-year mean annual temperature and precipitation for the region is $9.5^{\circ} \mathrm{C}$ and $889 \mathrm{~mm}$, respectively. The KBG was maintained at a 7.6-cm height of cut using a rotary-mower three times per week ${ }^{-1}$ and the clippings were returned to the plots. Irrigation was applied throughout the growing season as needed to prevent drought stress.

\subsection{Treatment Structure}

Treatments were arranged in a randomized complete block design with three replications. Fertilizer treatments included: synthetic fertilizer with black gypsum (SFBG; The Andersons, Inc., Maumee, OH, USA), poly-coated humic-coated urea (PCHCU; two rates; The Andersons, Inc., Maumee, OH, USA), urea (The Andersons, Inc., Maumee, OH, USA) + humic dispersing granules (HDG; two rates; The Andersons, Inc., Maumee, OH, USA), urea, stabilized nitrogen (Koch Agronomic Services, LLC, Wichita, KS, USA), HDG, and a nontreated control (Table 2). Applications were made using a wooden box with offsetting wire mesh to ensure uniform fertilizer distribution across the plots. Fertilizer treatments were applied in April, May, September, and October in 2019 and 2020, and were made to the same experimental units throughout the duration of the study. 
Table 2. Fertilizer treatments, nutrient analysis, and application rates.

\begin{tabular}{|c|c|c|}
\hline Treatment $^{1}$ & Nutrient Analysis & Application Rate \\
\hline Synthetic fertilizer with black gypsum (SFBG) ${ }^{2}$ & $\begin{array}{c}22 \mathrm{~N}-0 \mathrm{P}-3.3 \mathrm{~K}, 30 \% \text { gypsum, } 4.7 \% \\
\text { humic acid }\end{array}$ & $48.8 \mathrm{~kg} \mathrm{~N} \mathrm{ha}^{-1}$ \\
\hline Poly-coated humic-coated urea (PCHCU) & $45 \mathrm{~N}-0 \mathrm{P}-0.2 \mathrm{~K}, 2 \%$ humic acid & $48.8 \mathrm{~kg} \mathrm{~N} \mathrm{ha}^{-1}$ \\
\hline PCHCU (0.75 rate) & $45 \mathrm{~N}-0 \mathrm{P}-0.2 \mathrm{~K}, 2 \%$ humic acid & $36.6 \mathrm{~kg} \mathrm{~N} \mathrm{ha}^{-1}$ \\
\hline Urea (0.75 rate) + humic dispersing granules (HDG) & $46 \mathrm{~N}-0 \mathrm{P}-0 \mathrm{~K}+70 \%$ humic acid & $36.6 \mathrm{~kg} \mathrm{~N}+44.9 \mathrm{~kg} \mathrm{HDG} \mathrm{ha}{ }^{-1}$ \\
\hline Urea $(0.5$ rate $)+$ HDG & $46 \mathrm{~N}-0 \mathrm{P}-0 \mathrm{~K}+70 \%$ humic acid & $24.4 \mathrm{~kg} \mathrm{~N}+44.9 \mathrm{~kg} \mathrm{HDG} \mathrm{ha}^{-1}$ \\
\hline Urea & $46 \mathrm{~N}-0 \mathrm{P}-0 \mathrm{~K}$ & $48 \mathrm{~kg} \mathrm{~N} \mathrm{ha}^{-1}$ \\
\hline Stabilized nitrogen & $46 \mathrm{~N}-0 \mathrm{P}-0 \mathrm{~K}$ & $48 \mathrm{~kg} \mathrm{~N} \mathrm{ha}^{-1}$ \\
\hline HDG & $70 \%$ humic acid & $44.9 \mathrm{~kg} \mathrm{HDG} \mathrm{ha}{ }^{-1}$ \\
\hline Nontreated & - & - \\
\hline
\end{tabular}

${ }^{1}$ Fertilizer treatments were applied in April, May, September, and October in 2019 and 2020 in Ames, IA, USA. ${ }^{2}$ Black gypsum is a combination of humic substances and gypsum.

\subsection{Data Collection}

\subsubsection{Visual Quality and Digital Image Analysis}

Turfgrass visual quality ratings were conducted biweekly using a 1-9 scale where $1=$ poor and $9=$ ideal, 6 or above being acceptable [44]. Digital images were collected biweekly to assess turfgrass quality following techniques used by Thoms et al. [45]. Digital images were subjected to digital image analysis (DIA) using the following threshold settings, hue 71 to 176 , saturation 10 to 100 , and brightness 0 to 100 . DIA was performed to determine percent green cover and dark green color index (DGCI) [46,47]. DGCI is an estimate of turfgrass health and DGCI values have been correlated to NDVI, green area biomass indexes, and nitrogen clipping content $[48,49]$.

\subsubsection{Clipping Biomass}

Clippings were collected monthly using a rotary-mower with an attached cloth bag, dried at $80^{\circ} \mathrm{C}$ for $3 \mathrm{~d}$, and weighed [22]. Prior to clipping collections, the turfgrass was allowed one week of growth to ensure enough tissue could be collected.

\subsubsection{Soil Physical and Chemical Parameters}

Soil moisture and soil compaction data were collected monthly and were measured on three random locations treatment ${ }^{-1}$ using a time domain reflectance (TDR) sensor (Field Scout 350, Spectrum Technologies Inc., Aurora, IL, USA) with 7.6-cm tines and a digital soil penetrometer (Turf-Tec International, Tallahassee, FL, USA) to a depth of $22.9 \mathrm{~cm}$, respectively.

Soil samples were collected to a depth of $5.1 \mathrm{~cm}$ for soil tests on 13 May and 31 October in 2019 and 2020 (after one fertilizer application and end of field season, respectively). Soil tests conducted by Solum, Inc. (Ames, IA, USA) and SureTech Laboratories (Indianapolis, IN, USA) were used to obtain soil nutrient concentrations, $\mathrm{pH}, \mathrm{CEC}$, and organic matter. Phosphorus (P), potassium (K), magnesium $(\mathrm{Mg})$, calcium (Ca), sulfur $(\mathrm{S})$, and zinc $(\mathrm{Zn})$ concentrations were determined using the Mehlich 3 extraction method [50]. The Mehlich 3 extractant solution was composed of $0.2 \mathrm{M}$ glacial acetic acid, $0.015 \mathrm{M}$ ammonium fluoride, $0.25 \mathrm{M}$ ammonium nitrate, $0.013 \mathrm{M}$ nitric acid, and $0.001 \mathrm{M}$ ethylenediaminetetraacetic acid (EDTA). Mehlich 3 extractions were analyzed using an inductively coupled plasma (ICP) spectrometer. The $\mathrm{pH}$ was measured in a $1: 2 \mathrm{CaCl}_{2}$ suspension, using $0.01 \mathrm{M} \mathrm{CaCl}$, and correlated back to 1:1 water. The CEC was calculated by the standard summation of the $\mathrm{cmol}_{\mathrm{C}}$ of $\mathrm{Ca}^{2+}+\mathrm{Mg}^{2+}+\mathrm{K}^{+}$acid portion. Soil organic matter values were determined using the loss-on-ignition method [51]. 


\subsubsection{Soil Microbial Biomass and Activity}

Soil cores were collected to a depth of $5.1 \mathrm{~cm}$ on 29 April and 17 October in 2019 and 2020 (after one fertilizer application and end of field season, respectively). Soils cores were sieved to 2-mm diameter particles before being used to determined soil microbial biomass, potential carbon $(\mathrm{C})$ mineralization, and potential net $\mathrm{N}$ mineralization.

Soil microbial biomass was determined using fresh soil. MBC and MBN were measured using the modified chloroform-fumigation extraction method [11,52,53]. Two subsets of soil samples $(5 \mathrm{~g})$ were used, one was placed in a $50 \mathrm{~mL}$ centrifuge tube and capped and one was placed in a $50 \mathrm{~mL}$ beaker. The $50 \mathrm{~mL}$ beakers were place into a desiccator along with $1 \mathrm{~mL}$ of chloroform. Both, the centrifuge tube and beakers sat for $24 \mathrm{~h}$ before extracting the soil with $25 \mathrm{~mL}$ of $0.5 \mathrm{M} \mathrm{K}_{2} \mathrm{SO}_{4}$. The fumigated and non-fumigated soil extracts were analyzed using a total organic carbon-total nitrogen (TOC-TN) analyzer (TOC-V-CPN, Shimadzu Scientific Instruments Inc., Columbia, MD, USA) to determine total organic $C$ and total N. MBC and MBN were corrected using 0.45 and 0.54 extraction efficiencies, respectively [54,55].

PMC was determined using methods described by McDaniel et al. [53] and McDaniel and Grandy [11]. Air-dried soil (5 g) placed in centrifuge tubes were brought up to $50 \%$ water-holding capacity, which provides near optimal water content for microbial respiration, and incubated for $14 \mathrm{~d}$ [56]. During the 14-d incubation, $\mathrm{CO}_{2}$ production was measured using a LI-830 $\mathrm{CO}_{2}$ analyzer (LI-COR, Lincoln, NE, USA). $\mathrm{CO}_{2}$ production measurements were taken $1,3,5,7,10,14 \mathrm{~d}$ after the start of the incubation. PMC was calculated as the cumulative $\mathrm{CO}_{2}$ produced over the 14-d incubation.

PMN was determined on the same incubated soils for PMC, using methods described by De et al. [57]. PMN was measured by extracting the total inorganic N (ammonium + nitrate) before and after the 14-d incubation using $2 \mathrm{M} \mathrm{KCl}$. Soil extract concentrations of ammonium $\left(\mathrm{NH}_{4}{ }^{+}\right)$and nitrate $\left(\mathrm{NO}_{3}{ }^{-}\right)$were determined colorimetrically using a Synerg HTX Multi-Mode Microplate Reader (BioTek Instruments, Inc., Winooski, VT, USA). $\mathrm{NH}_{4}{ }^{+}$ $\mathrm{N}$ was measured using salicylate and ammonia cyanurate reagent packets (Hach Company, Loveland, $\mathrm{CO}, \mathrm{USA}$ ) and a $595 \mathrm{~nm}$ wavelength. $\mathrm{NO}_{3}{ }^{-}-\mathrm{N}$ was measured using the single reagent method (vanadium [III], sulfanilamide, and N-[1-naphthyl]-ethylenediamine dihydrochloride) and a $540 \mathrm{~nm}$ wavelength. PMN was calculated by subtracting the initial total inorganic $\mathrm{N}$ from the total inorganic $\mathrm{N}$ after the 14-d incubation.

\subsection{Statistical Analysis}

All data collected were subjected to analysis of variance (ANOVA) with repeated measures using SAS (version 9.4; SAS Institute Inc., Cary, NC, USA). The experiment was repeated in time. Treatment means for soil moisture, compaction, nutrient concentrations, $\mathrm{pH}, \mathrm{CEC}$, organic matter, microbial biomass, $\mathrm{PMC}$, and PMN have been combined across years and data collection dates due to a non-significant interaction with treatment effect. A significant year-by-rating date-by-treatment interaction was present for turfgrass visual quality, percent green cover, and clipping collections, data are presented by year and rating date. A significant rating date-by-treatment interaction was present for DGCI, data described by rating date. Fertilizer treatment mean comparisons were separated using Fisher's protected least significant difference (LSD) at the $p \leq 0.05$ level.

\section{Results}

\subsection{Visual Quality and Digital Image Analysis}

Fertilizer treatments resulted in a significant effect on visual quality ratings on all but one of the rating dates between the two years (Table 3). On two weeks after initial treatment (WAIT) in 2019, there were no differences in visual quality between the treatments. All rating dates after two WAIT in 2019 had differences between treatments. All treatments that received $\mathrm{N}$ had acceptable visual quality ratings (six or above) throughout the duration of the study. HDG and the nontreated control had 12 and 17 rating dates, respectively, below the minimally acceptable level. Treatments with reduced rates of $\mathrm{N}$, which were 
PCHCU (0.75 rate), urea (0.75 rate) + HDG, and urea (0.5 rate) + HDG, performed similarly in to terms of visual quality to the full $\mathrm{N}$ rate treatments. Overall, fertilizer treatments that had $\mathrm{N}$, including the treatments with reduced $\mathrm{N}$ rates, outperformed HDG and the nontreated control for visual quality.

Table 3. Effects of various fertilizers on visual quality ratings (1-9 scale where $1=$ poor and $9=$ ideal, 6 or above being acceptable) of a native soil Kentucky bluegrass maintained at $7.6 \mathrm{~cm}$ in Ames, IA, USA in 2019 and 2020.

\begin{tabular}{|c|c|c|c|c|c|c|c|c|c|c|c|c|c|c|}
\hline \multirow{2}{*}{ Treatment ${ }^{1}$} & \multicolumn{14}{|c|}{ Weeks After Initial Treatment } \\
\hline & 2 & 4 & 6 & 8 & 10 & 12 & 14 & 16 & 18 & 20 & 22 & 24 & 26 & 28 \\
\hline & \multicolumn{14}{|c|}{2019 Visual Quality } \\
\hline $\begin{array}{l}\text { Synthetic fertilizer with black } \\
\text { gypsum (SFBG) }\end{array}$ & 7.3 & 7.7 & 8.3 & 7.3 & 7.0 & 7.3 & 7.3 & 7.7 & 7.0 & 7.3 & 8.0 & 7.7 & 7.7 & 6.7 \\
\hline $\begin{array}{c}\text { Poly-coated humic-coated } \\
\text { urea (PCHCU) }\end{array}$ & 7.3 & 7.0 & 8.0 & 7.3 & 7.3 & 7.3 & 7.3 & 7.0 & 7.0 & 6.7 & 8.0 & 8.3 & 7.3 & 7.0 \\
\hline PCHCU (0.75 rate) & 7.0 & 7.3 & 7.7 & 7.3 & 6.7 & 6.7 & 7.0 & 7.3 & 7.0 & 6.7 & 7.7 & 7.3 & 7.7 & 6.7 \\
\hline $\begin{array}{c}\text { Urea }(0.75 \text { rate })+\text { humic } \\
\text { dispersing granules (HDG) }\end{array}$ & 7.7 & 7.0 & 7.7 & 7.3 & 6.7 & 7.0 & 7.0 & 7.3 & 7.0 & 6.7 & 7.0 & 7.7 & 7.7 & 7.0 \\
\hline Urea (0.5 rate) + HDG & 8.0 & 6.3 & 7.3 & 7.0 & 6.7 & 7.0 & 7.3 & 7.0 & 7.0 & 7.0 & 7.0 & 7.7 & 7.0 & 6.0 \\
\hline Urea & 7.3 & 7.7 & 7.3 & 7.0 & 7.3 & 6.7 & 7.0 & 7.0 & 7.0 & 6.7 & 7.7 & 7.3 & 7.0 & 6.3 \\
\hline Stabilized nitrogen & 7.7 & 6.7 & 7.7 & 7.3 & 7.0 & 7.3 & 7.7 & 7.3 & 7.3 & 6.7 & 7.7 & 7.3 & 6.7 & 6.7 \\
\hline HDG & 6.7 & 5.3 & 6.0 & 5.7 & 5.3 & 5.7 & 6.0 & 6.0 & 5.7 & 6.0 & 6.3 & 6.0 & 6.3 & 5.3 \\
\hline Nontreated & 7.3 & 4.7 & 6.0 & 5.3 & 5.0 & 5.3 & 5.3 & 5.7 & 5.7 & 5.3 & 5.3 & 5.3 & 6.0 & 5.3 \\
\hline \multirow[t]{2}{*}{$\mathrm{LSD}_{0.05}{ }^{2}$} & $\mathrm{NS}^{3}$ & 1.8 & 1.0 & 1.0 & 0.9 & 1.1 & 0.8 & 0.8 & 0.6 & 1.1 & 1.0 & 0.9 & 0.8 & 0.8 \\
\hline & \multicolumn{14}{|c|}{2020 Visual Quality } \\
\hline $\begin{array}{l}\text { Synthetic fertilizer with black } \\
\text { gypsum (SFBG) }\end{array}$ & 8.0 & 8.3 & 8.0 & 7.7 & 7.7 & 7.3 & 7.3 & 8.3 & 8.0 & 7.7 & 8.3 & 8.0 & 8.7 & 8.7 \\
\hline $\begin{array}{c}\text { Poly-coated humic-coated } \\
\text { urea (PCHCU) }\end{array}$ & 7.7 & 8.3 & 8.3 & 8.0 & 8.3 & 8.7 & 8.0 & 8.0 & 8.3 & 8.3 & 8.3 & 8.3 & 8.7 & 8.7 \\
\hline PCHCU (0.75 rate) & 7.0 & 7.7 & 7.7 & 7.3 & 7.7 & 7.7 & 8.0 & 7.3 & 7.3 & 7.7 & 8.0 & 7.7 & 8.3 & 7.7 \\
\hline $\begin{array}{l}\text { Urea ( } 0.75 \text { rate })+ \text { humic } \\
\text { dispersing granules (HDG) }\end{array}$ & 6.7 & 7.7 & 7.7 & 7.0 & 7.7 & 8.0 & 7.7 & 7.7 & 7.0 & 7.7 & 7.7 & 8.0 & 8.7 & 8.0 \\
\hline Urea (0.5 rate) + HDG & 6.0 & 7.3 & 8.0 & 7.0 & 7.0 & 8.0 & 7.3 & 7.7 & 7.3 & 7.3 & 7.0 & 7.3 & 7.3 & 7.3 \\
\hline Urea & 7.0 & 8.0 & 7.7 & 7.0 & 7.7 & 8.0 & 8.0 & 7.7 & 7.3 & 7.3 & 7.7 & 8.3 & 8.0 & 7.7 \\
\hline Stabilized nitrogen & 7.0 & 7.7 & 8.0 & 7.7 & 8.0 & 8.0 & 7.7 & 7.3 & 7.7 & 7.7 & 8.0 & 7.7 & 8.0 & 7.7 \\
\hline HDG & 4.7 & 6.0 & 6.3 & 6.0 & 6.3 & 6.7 & 7.0 & 6.0 & 5.7 & 6.0 & 5.3 & 5.3 & 4.7 & 4.7 \\
\hline Nontreated & 4.7 & 6.0 & 5.3 & 6.0 & 6.0 & 6.0 & 6.0 & 5.7 & 5.3 & 5.0 & 5.0 & 4.7 & 4.0 & 4.7 \\
\hline $\mathrm{LSD}_{0.05}$ & 1.0 & 1.1 & 1.1 & 0.9 & 0.7 & 1.3 & 0.9 & 1.2 & 0.9 & 1.1 & 0.9 & 1.4 & 1.2 & 0.9 \\
\hline
\end{tabular}

${ }^{1}$ Fertilizer treatments were applied in April, May, September, and October in 2019 and 2020. SFBG, PCHCU, urea, and stabilized nitrogen were applied at $48.8 \mathrm{~kg} \mathrm{~N}^{-1}, \mathrm{PCHCU}\left(0.75\right.$ rate) and urea $\left(0.75\right.$ rate) were applied at $36.6 \mathrm{~kg} \mathrm{~N} \mathrm{ha}^{-1}$, urea (0.5 rate) was applied at $24.4 \mathrm{~kg} \mathrm{~N} \mathrm{ha}^{-1}$, and HDG were applied at $44.9 \mathrm{~kg} \mathrm{HDG} \mathrm{ha}^{-1} .{ }^{2}$ Treatment mean comparisons were separated using Fisher's protected least significant difference (LSD) at the $p \leq 0.05$ level. ${ }^{3} \mathrm{NS}$, nonsignificant at the 0.05 probability level.

Fertilizer treatments had a significant effect on percent green cover on 15 of the 30 rating dates across the two years (Table 4). There was no differences in percent green cover until four WAIT in 2019 and two WAIT in 2020. After fertilizer applications were made (after 0 WAIT in 2019 and 2020), all treatments that received N maintained percent green cover over $90 \%$ throughout the duration of the study. HDG and the nontreated control had four and five rating dates, respectively, below $90 \%$ green cover after initial fertilizer applications. In terms of percent green cover, treatments with reduced $\mathrm{N}$ rates performed similarly to the full $\mathrm{N}$ rate treatments. Overall, treatments that have $\mathrm{N}$, including the treatments with reduced $\mathrm{N}$ rates, had a greater percent green cover compared to HDG and the nontreated control. 
Table 4. Effects of various fertilizers on percent green cover, determined by digital image analysis, of a native soil Kentucky bluegrass maintained at $7.6 \mathrm{~cm}$ in Ames, IA, USA in 2019 and 2020.

\begin{tabular}{|c|c|c|c|c|c|c|c|c|c|c|c|c|c|c|c|}
\hline \multirow{2}{*}{ Treatment $^{1}$} & \multicolumn{15}{|c|}{ Weeks After Initial Treatment } \\
\hline & 0 & 2 & 4 & 6 & 8 & 10 & 12 & 14 & 16 & 18 & 20 & 22 & 24 & 26 & 28 \\
\hline & \multicolumn{15}{|c|}{2019 Green Cover (\%) } \\
\hline $\begin{array}{l}\text { Synthetic fertilizer with black } \\
\text { gypsum (SFBG) }\end{array}$ & 58.3 & 94.4 & 98.2 & 99.0 & 93.2 & 90.9 & 90.5 & 96.0 & 98.4 & 97.9 & 97.8 & 98.2 & 96.9 & 96.3 & 95.7 \\
\hline $\begin{array}{l}\text { Poly-coated humic-coated urea } \\
\text { (PCHCU) }\end{array}$ & 57.7 & 95.2 & 97.8 & 98.8 & 94.9 & 92.7 & 94.8 & 95.9 & 98.4 & 98.1 & 97.1 & 97.9 & 96.2 & 95.6 & 96.3 \\
\hline PCHCU (0.75 rate) & 59.7 & 96.1 & 98.6 & 99.0 & 93.3 & 92.1 & 93.1 & 94.8 & 97.6 & 97.2 & 97.4 & 98.4 & 97.1 & 96.9 & 94.8 \\
\hline $\begin{array}{c}\text { Urea }(0.75 \text { rate })+\text { humic } \\
\text { dispersing granules (HDG) }\end{array}$ & 61.4 & 95.4 & 98.4 & 98.8 & 94.4 & 90.0 & 90.3 & 95.6 & 97.7 & 97.7 & 95.2 & 98.2 & 96.6 & 96.7 & 95.8 \\
\hline Urea (0.5 rate) + HDG & 61.0 & 93.5 & 97.9 & 98.1 & 91.5 & 90.5 & 92.7 & 93.8 & 97.3 & 97.5 & 96.1 & 6.2 & 94.7 & 4.0 & 92.4 \\
\hline Urea & 57.6 & 95.9 & 98.6 & 99.0 & 93.8 & 93.8 & 90.3 & 93.6 & 97.5 & 97.1 & 97.0 & 98.1 & 95.9 & 95.6 & 95.0 \\
\hline Stabilized nit & 60.5 & 94.4 & 98.2 & 97.1 & 93.2 & 92.4 & 90.5 & 96.3 & 98.7 & 98.3 & 95.9 & 97.6 & 95.3 & 94.8 & 94.7 \\
\hline HDG & 60.2 & 93.3 & 96.8 & 97.9 & 94.8 & 90.1 & 94.4 & 93.0 & 96.7 & 95.7 & 96.4 & 95.7 & 94.9 & 93.2 & 89.1 \\
\hline Nontreated & 59.7 & 91.7 & 94.0 & 94.7 & 88.9 & 90.7 & 92.3 & 92.9 & 95.7 & 96.6 & 94.9 & 94.6 & 92.4 & 91.6 & 87.0 \\
\hline \multirow[t]{2}{*}{$\mathrm{LSD}_{0.05}{ }^{2}$} & $S^{3}$ & NS & 1.6 & 1.5 & NS & NS & NS & NS & 1.6 & NS & 1.5 & 2.0 & 2.4 & 2.4 & 4.0 \\
\hline & \multicolumn{15}{|c|}{2020 Green Cover $(\%)$} \\
\hline $\begin{array}{l}\text { Synthetic fertilizer with black } \\
\text { gypsum (SFBG) }\end{array}$ & 73.6 & 98.8 & 98.7 & 99.5 & 95.7 & 93.2 & 92.1 & 94.9 & 97.8 & 97.2 & 97.3 & 95.4 & 95.4 & 92.9 & 93.5 \\
\hline $\begin{array}{l}\text { Poly-coated humic-coated urea } \\
\text { (PCHCU) }\end{array}$ & 76.6 & 9 & 98. & 99.6 & 96.9 & 96.4 & 95.6 & 96.4 & 98.8 & 98.7 & 98.0 & 96.8 & 97.4 & 95.5 & 95.1 \\
\hline PCHCU (0.75 rate) & 78.6 & 98.2 & 98.8 & 99.6 & 96.3 & 94.5 & 93.3 & 94.7 & 97.9 & 97.3 & 97.8 & 96.1 & 96.0 & 95.5 & 93.5 \\
\hline $\begin{array}{c}\text { Urea ( } 0.75 \text { rate })+ \text { humic } \\
\text { dispersing granules (HDG) }\end{array}$ & 78.6 & 97.5 & 98.7 & 99.5 & 96.3 & 94.9 & 94.3 & 94.8 & 97.7 & 97.5 & 97.0 & 95.4 & 94.3 & 95.3 & 95.2 \\
\hline Urea (0.5 rate) + HDG & 69.5 & 95.4 & 98.0 & 99.5 & 95.9 & 93.8 & 94.2 & 94.1 & 96.5 & 96.3 & 96.1 & 96.3 & 94.3 & 94.7 & 93.5 \\
\hline Urea & 69.7 & 96.7 & 99.0 & 99.6 & 96.3 & 94.7 & 94.7 & 95.4 & 97.5 & 97.9 & 97.5 & 96.5 & 96.4 & 96.1 & 95.3 \\
\hline Stabilized nitrogen & 78.2 & 97.0 & 98.5 & 99.7 & 96.8 & 95.5 & 95.6 & 96.5 & 98.7 & 98.4 & 98.1 & 97.2 & 96.4 & 94.8 & 93.4 \\
\hline HDG & 67.9 & 92.1 & 95.0 & 99.3 & 97.1 & 95.2 & 93.7 & 93.4 & 95.6 & 96.2 & 96.7 & 90.3 & 86.5 & 80.2 & 68.9 \\
\hline Nontreated & 64.8 & 91.6 & 93.8 & 99.3 & 96.9 & 95.3 & 96.0 & 92.5 & 94.7 & 96.0 & 96.8 & 92.3 & 88.5 & 86.7 & 77.1 \\
\hline $\mathrm{LSD}_{0.05}$ & NS & 2.8 & 2.2 & NS & NS & NS & NS & NS & 1.6 & 1.7 & NS & NS & 3.1 & 5.6 & 7.7 \\
\hline
\end{tabular}

${ }^{1}$ Fertilizer treatments were applied in April, May, September, and October in 2019 and 2020. SFBG, PCHCU, urea, and stabilized nitrogen were applied at $48.8 \mathrm{~kg} \mathrm{~N} \mathrm{ha}^{-1}, \mathrm{PCHCU}\left(0.75\right.$ rate) and urea ( 0.75 rate) were applied at $36.6 \mathrm{~kg} \mathrm{~N} \mathrm{ha}^{-1}$, urea (0.5 rate) was applied at $24.4 \mathrm{~kg} \mathrm{~N} \mathrm{ha}^{-1}$, and HDG were applied at $44.9 \mathrm{~kg} \mathrm{HDG} \mathrm{ha}{ }^{-1} .{ }^{2}$ Treatment mean comparisons were separated using Fisher's protected least significant difference (LSD) at the $p \leq 0.05$ level. ${ }^{3} \mathrm{NS}$, nonsignificant at the 0.05 probability level.

Fertilizer treatments had a significant effect on DGCI on five of the 15 rating dates. On average across the rating dates, the DGCI of the treatments ranged from 0.71 to 0.87 . However, minimal differences were observed between treatments. Within each rating date, the treatment differences in DGCI varied from 0.01 to 0.05 . Overall, only a few rating dates showed treatment differences in DGCI and the differences were minimal.

\subsection{Clipping Biomass}

Fertilizer treatments had a significant effect on clipping biomass on nine of the 12 collection dates across the two years (Table 5). One month after initial treatment (MAIT) in 2019, SFBG (26.2 g), urea (26.1 g), PCHCU (0.75 rate) (25.1 g), and PCHCU (22.3 g) had a greater clipping biomass compared to HDG $(6.0 \mathrm{~g})$ and the nontreated control $(10.2 \mathrm{~g})$. Two MAIT in 2019, PCHUC (12.6 g) and SFBG (12.1 g) had more clipping biomass compared to HDG $(6.5 \mathrm{~g})$ and the nontreated control $(5.8 \mathrm{~g})$. There were no differences in clipping biomass three and four MAIT in 2019. Five MAIT in 2019, SFBG (19.2 g) and PCHCU $(17.6 \mathrm{~g})$ had higher clipping biomass relative to HDG $(8.3 \mathrm{~g})$ and the nontreated control (9.5 g). Six MAIT in 2019, SFBG (4.5 g) and PCHCU (0.75 rate) (3.6 g) had greater clipping biomass compared to HDG (1.9 g) and the nontreated control (3.0 g). One MAIT in 2020, only SFBG (19.1 g) had a higher clipping biomass relative to HDG (3.9 g) and the nontreated control $(5.0 \mathrm{~g})$. There was no differences in biomass two MAIT in 2020. Three and 
four MAIT in 2020, there were no treatments with greater clipping biomass relative to the nontreated control. All treatments had a more clipping biomass compared to HDG (0.3 g) and the nontreated control $(0.7 \mathrm{~g})$ five MAIT in 2020, with SFBG $(6.4 \mathrm{~g})$ having the greatest clipping biomass. Six MAIT in 2020, SFBG (15.4 g) was the only treatment to have a greater clipping biomass compared to HDG (4.4 g) and the nontreated control (6.5 g). Only SFBG, PCHCU, and urea had multiple collection dates with greater clipping biomass compared to the treatments that did not receive N (HDG and the nontreated control). Treatments with reduced $\mathrm{N}$ rates slightly increased clipping biomass compared to treatments that received no $\mathrm{N}$. However, treatments with reduced $\mathrm{N}$ rates resulted in less clipping biomass accumulation, on average, compared to treatments with full $\mathrm{N}$ rates.

Table 5. Effects of various fertilizers on clipping dry weight of a native soil Kentucky bluegrass maintained at $7.6 \mathrm{~cm}$ in Ames, IA, USA in 2019 and 2020.

\begin{tabular}{|c|c|c|c|c|c|c|}
\hline Treatment $^{1}$ & May & June & July & August & September & October \\
\hline & \multicolumn{6}{|c|}{2019 Clippings $^{2}(\mathrm{~g})$} \\
\hline Synthetic fertilizer with black gypsum (SFBG) & 26.2 & 12.1 & 17.0 & 4.3 & 19.2 & 4.5 \\
\hline Poly-coated humic-coated urea (PCHCU) & 22.3 & 12.6 & 15.8 & 2.9 & 17.6 & 2.8 \\
\hline PCHCU (0.75 rate) & 25.1 & 9.1 & 16.0 & 3.1 & 16.7 & 3.6 \\
\hline Urea (0.75 rate) + humic dispersing granules (HDG) & 18.6 & 9.3 & 11.5 & 2.3 & 12.7 & 2.6 \\
\hline Urea (0.5 rate) + HDG & 17.8 & 11.3 & 17.6 & 4.6 & 12.0 & 3.2 \\
\hline Urea & 26.1 & 10.4 & 15.0 & 2.4 & 14.9 & 2.1 \\
\hline Stabilized nitrogen & 18.7 & 6.9 & 14.6 & 3.1 & 11.9 & 2.5 \\
\hline HDG & 6.0 & 6.5 & 10.7 & 2.0 & 8.3 & 1.9 \\
\hline Nontreated & 10.2 & 5.8 & 13.6 & 3.2 & 9.5 & 3.0 \\
\hline \multirow[t]{2}{*}{$\mathrm{LSD}_{0.05}{ }^{3}$} & 9.1 & 5.0 & $\mathrm{NS}^{4}$ & NS & 7.4 & 1.2 \\
\hline & \multicolumn{6}{|c|}{2020 Clippings (g) } \\
\hline Synthetic fertilizer with black gypsum (SFBG) & 19.1 & 4.9 & 4.3 & 4.8 & 6.4 & 15.4 \\
\hline Poly-coated humic-coated urea (PCHCU) & 11.5 & 4.7 & 6.1 & 5.8 & 5.4 & 12.5 \\
\hline PCHCU (0.75 rate) & 11.9 & 4.7 & 3.6 & 3.8 & 4.1 & 12.6 \\
\hline Urea ( 0.75 rate) + humic dispersing granules (HDG) & 10.6 & 4.1 & 2.5 & 2.6 & 3.2 & 10.9 \\
\hline Urea (0.5 rate) + HDG & 7.3 & 4.8 & 4.5 & 4.5 & 2.5 & 11.6 \\
\hline Urea & 11.8 & 4.2 & 4.1 & 4.2 & 4.0 & 11.6 \\
\hline Stabilized nitrogen & 8.5 & 4.1 & 6.7 & 4.7 & 2.8 & 8.7 \\
\hline HDG & 3.9 & 3.6 & 1.2 & 1.0 & 0.3 & 4.4 \\
\hline Nontreated & 5.0 & 4.2 & 3.5 & 3.1 & 0.7 & 6.5 \\
\hline $\mathrm{LSD}_{0.05}$ & 7.2 & NS & 3.4 & 3.7 & 1.4 & 6.4 \\
\hline
\end{tabular}

${ }^{1}$ Fertilizer treatments were applied in April, May, September, and October in 2019 and 2020. SFBG, PCHCU, urea, and stabilized nitrogen were applied at $48.8 \mathrm{~kg} \mathrm{~N}^{-1}$, PCHCU (0.75 rate) and urea ( 0.75 rate) were applied at $36.6 \mathrm{~kg} \mathrm{~N}$ ha- 1 , urea ( 0.5 rate) was applied at $24.4 \mathrm{~kg} \mathrm{~N} \mathrm{ha}^{-1}$, and HDG were applied at $44.9 \mathrm{~kg} \mathrm{HDG} \mathrm{ha}^{-1} .{ }^{2}$ Clippings were collected after one week of growth using a rotary-mower with an attached cloth bag, dried at $80^{\circ} \mathrm{C}$ for $3 \mathrm{~d}$, and weighed. ${ }^{3}$ Treatment mean comparisons were separated using Fisher's protected least significant difference (LSD) at the $p \leq 0.05$ level. ${ }^{4} \mathrm{NS}$, nonsignificant at the 0.05 probability level.

\subsection{Soil Physical and Chemical Parameters}

Fertilizer treatments did not have an effect on soil $\mathrm{P}, \mathrm{K}, \mathrm{Mg}, \mathrm{Ca}$, and $\mathrm{Zn}$ concentrations, $\mathrm{pH}, \mathrm{CEC}$, organic matter, moisture, and compaction (Table S1). Soil $\mathrm{P}, \mathrm{K}, \mathrm{Mg}, \mathrm{Ca}$, and Zn concentrations ranged from 14.0 to $18.8 \mathrm{mg} \mathrm{kg}^{-1}, 101.4$ to $125.4 \mathrm{mg} \mathrm{kg}^{-1}, 570.2$ to $599.2 \mathrm{mg} \mathrm{kg}^{-1}, 2247.2$ to $2383.5 \mathrm{mg} \mathrm{kg}^{-1}$, and 1.8 to $5.4 \mathrm{mg} \mathrm{kg}^{-1}$, respectively. The $\mathrm{pH}$ in the soil samples varied from 6.9 to 7.1 . The CEC ranged from 15.9 to $16.8 \mathrm{cmol}_{\mathrm{c}} \mathrm{kg}^{-1}$. Soil organic matter varied from 4.2 to 4.6 percent. On average throughout the duration of the experiment, soil moisture and soil compaction varied from 36.3 to $38.3 \%(v / v)$ and 1210 to $1346 \mathrm{kPa}$, respectively. SFBG resulted in the highest soil S concentration $\left(7.5 \mathrm{mg} \mathrm{kg}^{-1}\right)$ compared to all of the other treatments $\left(4.8-5.0 \mathrm{mg} \mathrm{kg}^{-1}\right)$. SFBG increased plant-available $\mathrm{S}$, extracted by the Mehlich 3 solution, by $52 \%$ compared to all other treatments. Overall, fertilizer treatments had little impact on soil $\mathrm{pH}, \mathrm{CEC}$, organic matter, and soil nutrient concentrations besides $\mathrm{S}$ concentrations. 


\subsection{Soil Microbial Biomass and Activity}

Fertilizer treatments did not have an effect on MBN, but did affect MBC (Table 6). MBC ranged from 481.3 to $546.4 \mathrm{mg} \mathrm{kg}^{-1}$. MBN ranged from 79.7 to $98.2 \mathrm{mg} \mathrm{kg}^{-1}$. PCHCU had a $14 \%$ greater MBC compared to urea ( 0.75 rate) + HDG. All other treatments were similar to PCHCU in terms of MBC. There were no differences in microbial C:N ratio.

Table 6. Effects of various fertilizers on soil microbial biomass carbon (MBC), microbial biomass nitrogen (MBN), carbon to nitrogen ratio $(\mathrm{C}: \mathrm{N})$, potentially mineralizable carbon (PMC), and potentially mineralizable net nitrogen (PMN) of a native soil Kentucky bluegrass maintained at $7.6 \mathrm{~cm}$ in Ames, IA, USA in 2019 and 2020.

\begin{tabular}{|c|c|c|c|c|c|}
\hline Treatment $^{1}$ & $\begin{array}{c}\mathrm{MBC}^{2} \\
\mathrm{mg} \mathrm{kg}\end{array}$ & $\begin{array}{c}\mathrm{MBN} \\
\mathbf{m g ~} \mathbf{k g}^{-1}\end{array}$ & $\mathrm{C}: \mathbf{N}$ & $\begin{array}{c}\mathrm{PMC}^{3} \\
\mathrm{mg} \mathrm{CO}_{2}-\mathrm{C}_{\mathrm{kg}^{-1}}\end{array}$ & $\begin{array}{c}\mathrm{PMN}^{4} \\
\mathrm{mg} \mathrm{N} \mathrm{kg}^{-1}\end{array}$ \\
\hline Synthetic fertilizer with black gypsum (SFBG) & $493.0^{5}$ & 79.7 & 7.0 & 416.0 & 13.2 \\
\hline Poly-coated humic-coated urea (PCHCU) & 546.4 & 88.9 & 7.0 & 394.0 & 14.0 \\
\hline PCHCU (0.75 rate) & 506.7 & 82.4 & 6.7 & 324.4 & 12.4 \\
\hline Urea (0.75 rate) + humic dispersing granules (HDG) & 481.3 & 98.2 & 6.5 & 237.4 & 11.1 \\
\hline Urea $(0.5$ rate $)+$ HDG & 508.9 & 83.0 & 6.9 & 243.0 & 10.9 \\
\hline Urea & 510.5 & 85.2 & 6.5 & 304.2 & 13.3 \\
\hline Stabilized nitrogen & 507.5 & 80.2 & 6.9 & 388.4 & 14.0 \\
\hline HDG & 520.8 & 82.2 & 7.1 & 315.4 & 11.8 \\
\hline Nontreated & 523.5 & 90.1 & 6.3 & 234.9 & 8.8 \\
\hline $\mathrm{LSD}_{0.05}{ }^{6}$ & 61.7 & $\mathrm{NS}^{7}$ & NS & 142.0 & 3.1 \\
\hline
\end{tabular}

${ }^{1}$ Fertilizer treatments were applied in April, May, September, and October in 2019 and 2020. SFBG, PCHCU, urea, and stabilized nitrogen were applied at $48.8 \mathrm{~kg} \mathrm{~N}^{-1}$, PCHCU (0.75 rate) and urea (0.75 rate) were applied at $36.6 \mathrm{~kg} \mathrm{~N}^{-1}$, urea (0.5 rate) was applied at $24.4 \mathrm{~kg} \mathrm{~N} \mathrm{ha}^{-1}$, and HDG were applied at $44.9 \mathrm{~kg} \mathrm{HDG} \mathrm{ha}^{-1}$. Soil cores were collected to a depth of $5.1 \mathrm{~cm}$ on 29 April and 17 October in 2019 and 2020 (after one fertilizer application and end of field season, respectively). ${ }^{2}$ MBC and MBN were determined by using the modified chloroform-fumigation extraction method. ${ }^{3} \mathrm{PMC}$ was determined by measuring the $\mathrm{CO}_{2}$ production during a 14 - $\mathrm{d}$ soil incubation. ${ }^{4}$ PMN was calculated by subtracting the initial total inorganic nitrogen (N) from the total inorganic $\mathrm{N}$ after the 14 -d incubation. Total inorganic N (ammonium and nitrate) was determined colorimetrically. ${ }^{5}$ No interaction between years, rating date, and treatment effect; means are pooled across years and rating dates. ${ }^{6}$ Treatment mean comparisons were separated using Fisher's protected least significant difference (LSD) at the $p \leq 0.05$ level. ${ }^{7} \mathrm{NS}$, nonsignificant at the 0.05 probability level.

Fertilizer treatments had stronger effects on biological activity (pool of labile $\mathrm{C}$ and $\mathrm{N}$ ) assessed by 14-d incubation (Table 6). SFBG, PCHCU, and stabilized nitrogen $\left(399.5 \mathrm{mg} \mathrm{CO} \mathrm{CO}_{2}-\mathrm{C} \mathrm{kg}^{-1}\right)$ had $68 \%$ greater PMC relative to urea $(0.5$ rate) $+\mathrm{HDG}$, urea (0.75 rate) $+\mathrm{HDG}^{-1}$, and the nontreated control $\left(238.4 \mathrm{mg} \mathrm{CO}_{2}-\mathrm{C} \mathrm{kg}^{-1}\right)$. PCHCU and stabilized nitrogen $\left(14.0 \mathrm{mg} \mathrm{N} \mathrm{kg}^{-1}\right)$ had a $41 \%$ greater PMN compared to urea ( 0.5 rate) + HDG and the nontreated control $\left(9.9 \mathrm{mg} \mathrm{N} \mathrm{kg}^{-1}\right)$. Urea, SFBG, and PCHCU (0.75 rate) (13.0 $\mathrm{mg} \mathrm{N} \mathrm{kg}^{-1}$ ) had $48 \%$ greater PMN relative to the nontreated control.

\section{Discussion}

\subsection{Turfgrass Plant Repsonse}

Humic products incorporated with $\mathrm{N}$ fertilizer enhanced turfgrass efficiency in both years of the study, thus allowed for lowering $\mathrm{N}$ rates while maintaining similar quality. All treatments that received $\mathrm{N}$, including treatments with reduced $\mathrm{N}$ rates, had increased turfgrass quality and percent cover compared to humic applications alone and the nontreated control. The addition of humic substances to $\mathrm{N}$ fertilizer did not increase turfgrass quality and percent cover compared to $\mathrm{N}$ fertilizer alone. This is consistent with Ervin et al. [33], who found that applications of humic acid did not improve turfgrass color or quality. Conversely, Zhu and Li [43], and Gao and Li [54] reported that applications of humic acid alone, and in a tank mix with fertilizer increased turfgrass quality. Reduced rates of $\mathrm{N}$ fertilizer applied with humic substances provided equivalent turfgrass quality and percent cover relative to full $\mathrm{N}$ rates, which could allow for a more sustainable fertilizer program.

In general, in both years of the study, treatments that received full $\mathrm{N}$ rates had greater clipping biomass compared to humic substances alone and the nontreated control. Furthermore, the addition of humic substances did not affect clipping yields. Ervin and 
Roberts [42], and Zhang and Schmidt [40] also found that applications of humic acid did not change shoot growth. In addition, Gao and Li [58] reported that the addition of humic substances to fertilizer tank mixes reduced clipping yields. Overall, reduced $\mathrm{N}$ rates in combination with humic substances slightly increased clipping biomass compared to treatments that received no $\mathrm{N}$ and had less clipping biomass correlative to treatments with full $\mathrm{N}$ rates. Applications of fertilizers with reduced $\mathrm{N}$ rates + humic substances reduced clipping biomass while maintaining acceptable turfgrass quality and cover, which indicates that mowing frequency can be reduced without reducing turfgrass quality [58].

\subsection{Turfgrass Soil Health}

Humic substances incorporated with $\mathrm{N}$ fertilizer products enhanced microbial activity, thus increasing the labile supply of $C$ and N. However, soil physical properties, soil moisture and compaction, were not impacted by fertilizer treatments during this experiment. Changes in physical soil properties can be difficult over short-term studies and normally have a slow response to management changes [3,5]. However, these results are different from Van Dyke et al. [36,59], who found that humic acid applications decreased soil volumetric water content and increased irrigation frequency. Although there were no changes in soil physical properties during this experiment, long-term humic fertilizer studies should be conducted to see if there would be any changes over a greater time period.

Fertilizer treatments did not have an effect on soil chemical properties besides soil $\mathrm{S}$ concentration. Chemical soil properties usually have a slow response to management changes and can be difficult to detect [3,5]. Hunter and Butler [60], and Zhu and Li [43] found that soil nutrient concentrations and organic matter did not increase with humic acid applications, which is consistent with the results found in this paper. Soil $\mathrm{pH}$ did not change from $\mathrm{N}$ fertilizers or $\mathrm{N}$ fertilizers + humic substances in this study. However, $\mathrm{Zhu}$ and $\mathrm{Li}$ [43], Zinati et al. [61], and Liu et al. [62] found that $\mathrm{N}$ fertilizers and humic acid applications decreased soil $\mathrm{pH}$. Soil S concentration increased with the application of SFBG, which was the only treatment that contained gypsum $\left(\mathrm{CaSO}_{4} \cdot 2 \mathrm{H}_{2} \mathrm{O}\right)$. Gypsum is a moderately soluble source of $\mathrm{S}$ and applications of gypsum have been shown to increase soil $S$ concentrations [63]. Long-term studies should be performed to determine if applications of humic fertilizers could affect soil chemical properties.

Fertilizer applications and the addition of humic substances had minimal effect on microbial biomass. The reason for no-effect may be due to minor amount of $C$ input compared to root exudation rates, and quality or chemical signal of the compounds just do not affect overall soil microbial biomass [64,65]. In mature turfgrass under different management intensities, MBC ranged from 249 to $1400 \mathrm{mg} \mathrm{kg}^{-1}$ and MBN ranged from 46 to $132 \mathrm{mg} \mathrm{kg}^{-1}$ [66-72]. Liu et al. [62] and Treseder [73] found that $\mathrm{N}$ fertilizer had no effect or decreased MBC and MBN. Conversely, Zhu and Li [43] found that applications of humic acid increased MBC by $17 \%$. Humic fertilizers should be applied in different turfgrass settings to determine if microbial biomass could be enhanced in different soil types [74].

Unlike microbial biomass, both $\mathrm{N}$ fertilizer rates and humic products affected potentially mineralizable pools of $C$ and N. Greater N fertilizer rates increased PMC by $40 \%$ and $37 \%$ relative to reduced $\mathrm{N}$ rates and treatments that received no $\mathrm{N}$, respectively. Moore et al. [75] reported that increasing $\mathrm{N}$ rates resulted in increasing PMC, which is consistent with the results found in this experiment. This is in contrast to other studies showing $\mathrm{N}$ fertilizer having no effect or decreasing PMC [62,66,73,76]. Differences in PMC due to $\mathrm{N}$ fertilizer may be explained by the rate of $\mathrm{N}$ used. Small amounts of $\mathrm{N}$ may increase PMC, but higher rates decrease PMC [26]. The addition of humic substance to fertilizers appears to have minimal effect on PMC. In mature turfgrass varying in management inputs, PMC ranged from 146 to $490 \mathrm{mg} \mathrm{CO}-\mathrm{C} \mathrm{kg}^{-1}[62,71,77]$. In general, in our study, fertilizer treatments with greater PMC also had increased clipping biomass, which is consistent with Moore et al. [78]. Moore et al. [78] also reported that increased PMC was correlated to im- 
proved turfgrass quality, which differs from the results in this paper. Fertilizer treatments with reduced $\mathrm{N}$ rates applied with humic substances generally had lower PMC, but still maintained turfgrass quality compared to full $\mathrm{N}$ rates.

Reduced $\mathrm{N}$ rates applied with humic substance had equivalent $\mathrm{PMN}$ relative to full $\mathrm{N}$ rates. It appears the addition of humic substances to fertilizers allows for reduced $\mathrm{N}$ rates while still maintaining similar PMN compared to full rate $\mathrm{N}$ fertilizer alone. Furthermore, applications of $\mathrm{N}$ fertilizer with or without humic substances increased PMN compared to the nontreated control. The increase in PMN with $\mathrm{N}$ fertilizer may be due to a $\mathrm{N}$ priming effect, which means that application of fertilizers increases the plant-available $\mathrm{N}$ in the soil [79]. In mature turfgrass with different management intensities, PMN ranged from 2.8 to $25.2 \mathrm{mg} \mathrm{N} \mathrm{kg}^{-1}[62,68,71,77]$. Similar to PMC, there is conflicting data on the effect of $\mathrm{N}$ fertilizer on PMN. Liu et al. [62] reported that $\mathrm{N}$ fertilizer had no effect on PMN and Yao et al. [66] found that N fertilizer reduced PMN. However, Moore et al. [75] found that increasing $\mathrm{N}$ fertilizer rates increased biological active $\mathrm{N}$ or PMN, which is similar to the results in this paper. In addition, fertilizer treatments that had an increased PMC also had a greater PMN. Moore et al. [71] also reported that greater PMC correlated with increased biological active or labile N. It appears that PMC could be used as an indicator or estimate of PMN in turfgrass soil. Furthermore, reduced $\mathrm{N}$ rate fertilizer treatments applied with humic substances result in similar PMN compared to full $\mathrm{N}$ rates, which suggest that reduced rate fertilizer programs that include humic substances could be a more sustainable turfgrass management strategy.

\section{Conclusions}

Overall, humic fertilizer treatments had minimal effect on soil physical and chemical properties besides soil S concentration. SFBG contains gypsum, which has been shown to increase soil $\mathrm{S}$ concentrations. Reduced rates of $\mathrm{N}$ fertilizer applied with humic substances provided equivalent turfgrass quality, percent cover, and reduced clipping biomass relative to full $\mathrm{N}$ rates, which could allow for reducing mowing frequency while sustaining acceptable turfgrass quality. Furthermore, reduced $\mathrm{N}$ rates with humic substances maintained biological soil health parameters compared to full rate $\mathrm{N}$ fertilizers, which suggest that the addition of humic substances allow for reductio in $\mathrm{N}$ rates without sacrificing overall soil health. In conclusion, humic substances can be applied with $\mathrm{N}$ fertilizers at reduced rates while providing acceptable turfgrass quality and cover, reducing clipping biomass, and maintaining soil health parameters compared to fertilizers applied at full $\mathrm{N}$ rates. Applications of reduced $\mathrm{N}$ fertilizer rates with the addition of humic substances could be incorporated into a more sustainable and environmentally friendly turfgrass fertilizer program.

Future research is needed to determine if $\mathrm{N}$ rates could be reduced further with the addition of humic substances while maintaining turfgrass quality. Additionally, research should be conducted to determine the optimal application timings and rates of the humic substances for enhanced microbial activity. Finally, future experiments should also be conducted on different soil types and climatic conditions to determine if the turfgrass and soil response to humic substances is widespread or site-specific.

Supplementary Materials: The following are available online at https:/ / www.mdpi.com/2073-4 395/11/2/395/s1, Table S1: Effects of various fertilizers on soil nutrient concentrations, $\mathrm{pH}$, cation exchange capacity, organic matter, moisture, and compaction of a native soil Kentucky bluegrass maintained at $7.6 \mathrm{~cm}$ in Ames, IA, USA in 2019 and 2020.

Author Contributions: Conceptualization, A.J.L., A.W.T., M.D.M. and N.E.C.; methodology, A.J.L., A.W.T., M.D.M. and N.E.C.; software, A.J.L. and M.D.M.; validation, A.J.L., A.W.T., M.D.M. and N.E.C.; formal analysis, A.J.L.; investigation, A.J.L. and A.W.T.; resources, A.J.L., A.W.T., and M.D.M.; data curation, A.J.L.; writing-original draft preparation, A.J.L.; writing—review and editing, A.J.L., A.W.T., M.D.M., and N.E.C.; visualization, A.J.L.; supervision, A.W.T.; project administration, A.J.L. and A.W.T.; funding acquisition, A.W.T. All authors have read and agreed to the published version of the manuscript. 
Funding: This research was funded by The Andersons, Inc. and the Iowa Turfgrass Institute.

Data Availability Statement: Data is contained within the article and supplementary material.

Acknowledgments: The authors would like to thank Anthony "Tony" Goldsby (The Andersons, Inc., Maumee, $\mathrm{OH}$, USA) for his assistance and for providing the products used in this research. Appreciation is extended to Isaac Mertz, Ben Pease, Tim Dalsgaard, Stephen Potter, Morgan Davis, Simon Mitbo, Colin Laswell, Nathan Underwood, and Ethan DenBeste for their help with experimental setup, data collection, and plot maintenance.

Conflicts of Interest: The authors declare no conflict of interest.

\section{References}

1. Doran, J. Soil health and global sustainablility: Tranlating science into practice. Agric. Ecosyst. Environ. 2002, 88, 119-127. [CrossRef]

2. Karlen, D.; Mausbach, M.; Doran, J.; Cline, R.; Harris, R.; Schuman, G. Soil quality: A concept, definition, and framework for evaluation. Soil Sci. Soc. Am. J. 1997, 61, 4-10. [CrossRef]

3. Cardoso, E.; Vasconcellos, R.; Bini, D.; Miyauchi, M.; dos Santos, C.; Alves, P.; de Paula, A.; Nakatani, A.; de Moraes Pereina, J.; Nogueira, M. Soil health: Looking for suitable indicators. What should be considered to assess the effects of use and management on soil health? Sci. Agric. 2013, 70, 274-289. [CrossRef]

4. Mann, C.; Lynch, D.; Fillmore, S.; Mills, A. Relationships between field management, soil health, and microbial community composition. Appl. Soil Ecol. 2019, 144, 12-21. [CrossRef]

5. Bünemann, E.; Bongiorno, G.; Bai, Z.; Creamer, R.; De Deyn, G.; de Goede, R.; Fleskens, L.; Geissen, V.; Kuyper, T.; Mäder, P.; et al. Soil quality-A critical review. Soil Biol. Biochem. 2018, 120, 105-125. [CrossRef]

6. Kibblewhite, M.; Ritz, K.; Swift, M. Soil health in agricultural systems. Phil. Trans. R. Soc. B 2008, 363, 685-701. [CrossRef] [PubMed]

7. Franzluebbers, A.; Haney, R.; Honeycutt, C.; Schomberg, H.; Hons, F. Flush of carbon dioxide following rewetting of dried soil relates to active organic pools. Soil Sci. Soc. Am. J. 2000, 64, 613-623. [CrossRef]

8. Franzluebbers, A.; Pershing, M.; Crozier, C.; Osmond, D.; Schroeder-Moreno, M. Soil-test biological activity with the flush of CO2: I. C and N characteristics of soils in corn production. Soil Sci. Soc. Am. J. 2018, 82, 685-695. [CrossRef]

9. Franzluebbers, A. Soil-test biological activity with the flush of CO2: III. Corn yield responses to applied nitrogen. Soil Sci. Soc. Am. J. 2018, 82, 708-721. [CrossRef]

10. Haney, R.; Hons, F.; Sanderson, M.; Franzluebbers, A. A rapid procedure for estimating nitrogen mineralization in manured soils. Biol. Fertil. Soils 2001, 33, 100-104. [CrossRef]

11. McDaniel, M.; Grandy, A. Soil microbial biomass and function are altered by 12 years of crop rotation. Soil 2016, 2, 583-599. [CrossRef]

12. IHSS. What Are Humic Substances? International Humic Substances Society. Available online: http://humic-substances.org/ \#reference (accessed on 27 January 2021).

13. Gerke, J. Concepts and misconceptions of humic substances as the stable part of soil organic matter: A review. Agronomy 2018, 8 , 76. [CrossRef]

14. Schmidt, R.; Ervin, E.; Zhang, X. Questions and answers about biostimulants. Golf Course Manag. 2003, 71, 91-94.

15. Pope, J.; Eichenberg, R.; Birthisel, T. Use of humate dispersible granule technology as a soil amendment in turfgrass and horticultural soils. Appl. Turfgrass Sci. 2013, 10, 38. [CrossRef]

16. Nardi, S.; Pizzeghello, D.; Muscolo, A.; Vianello, A. Physiological effects of humic substances on higher plants. Soil Biol. Biochem. 2002, 34, 1527-1536. [CrossRef]

17. Trevisan, S.; Francioso, O.; Quaggiotti, S.; Nardi, S. Humic substances biological activity at the plant-soil interface. Plant Signal. Behav. 2010, 5, 635-643. [CrossRef]

18. Canellas, L.; Olivares, F.; Aguiar, N.; Jones, D.; Nebioso, A.; Mazzei, P.; Piccolo, A. Humic and fulvic acids as biostimulants in horticulture. Sci. Hortic. 2015, 196, 15-27. [CrossRef]

19. Canellas, L.; Olivares, F. Physiological responses to humic substances as plant growth promoter. Chem. Biol. Technol. Agric. 2014, 1, 3. [CrossRef]

20. Liu, C.; Cooper, R. Humic substances influence creeping bentgrass growth. Carbon 2000, 54, 41-51.

21. Pettit, R. Organic matter, humus, humate, humic acid, fulvic acid and humin: Their importance in soil fertility and plant health. CTI Res. 2004, 1-17.

22. Lindsey, A.; Thoms, A.; Christians, N. Kentucky bluegrass and bermudagrass rooting response to humic fertilizers during greenhouse establishment. Agron. J. 2020, 112, 3396-3401. [CrossRef]

23. Cheng, Y.; Wang, J.; Wang, J.; Chang, S.; Wang, S. The quality and quantity of exogenous organic carbon input control microbial NO3- immobilization: A meta-analysis. Soil Biol. Biochem. 2017, 115, 357-363. [CrossRef]

24. Magill, A.; Aber, J. Variation in soil net mineralization rates with dissolved organic carbon additions. Soil Biol. Biochem. 2000, 32, 597-601. [CrossRef] 
25. Ramirez, K.; Craine, J.; Fierer, N. Nitrogen fertilization inhibits soil microbial respiration regardless of the form of nitrogen applied. Soil Biol. Biochem. 2010, 42, 2336-2338. [CrossRef]

26. Grandy, A.; Salam, D.; Wickings, K.; McDaniel, M.; Culman, S.; Snapp, S. Soil respiration and litter decomposition responses to nitrogen fertilization rate in no-till corn systems. Agric. Ecosyst. Environ. 2013, 179, 35-40. [CrossRef]

27. Wang, C.; Liu, D.; Bai, E. Decreasing soil microbial diversity is associated with decreasing microbial biomass under nitrogen addition. Soil Biol. Biochem. 2018, 120, 126-133. [CrossRef]

28. Cooper, R.; Liu, C.; Fisher, D. Influence of humic substances on rooting and nutrient content of creeping bentgrass. Crop Sci. 1998, 38, 1639-1644. [CrossRef]

29. Liu, C.; Cooper, R.; Bowman, D. Humic acid application affects photosynthesis, root development, and nutrient content of creeping bentgrass. HortScience 1998, 33, 1023-1025. [CrossRef]

30. Zhang, X.; Schmidt, R. Hormone-containing products' impact on antioxidant status of tall fescue and creeping bentgrass subjected to drought. Crop Sci. 2000, 40, 1344-1349. [CrossRef]

31. Zhang, X.; Schmidt, R.; Ervin, E.; Doak, S. Creeping bentgrass physiological responses to natural plant growth regulators and iron under two regimes. HortScience 2002, 37, 898-902. [CrossRef]

32. Zhang, X.; Ervin, E.; Schmidt, R. Physiological effects of liquid applications of a seaweed extract and a humic acid on creeping bentgrass. J. Am. Soc. Hortic. Sci. 2003, 128, 492-496. [CrossRef]

33. Ervin, E.; Zhang, X.; Goatley, J.; Askew, S. Trinexapac-ethyl, propiconazole, iron, and biostimulant effects on shaded creeping bentgrass. HortTechnology 2004, 14, 500-506. [CrossRef]

34. Zhang, X.; Ervin, E. Cytokinin-containing seaweed and humic acid extracts associated with creeping bentgrass leaf cytokinins and drought resistance. Crop Sci. 2004, 44, 1737-1745. [CrossRef]

35. Clapp, C.; Shenker, M.; Hayes, M.; Liu, R.; Cline, V.; Palazzo, A.; Chen, Y. Microsystems for rapid evaluation of plant growth response to organic amendments. Soil Sci. 2008, 173, 342-349. [CrossRef]

36. Van Dyke, A.; Johnson, P.; Grossl, P. Influence of humic acid on water retention and nutrient acquisition in simulated golf putting greens. Soil Use Manag. 2009, 25, 255-261. [CrossRef]

37. Zhang, X.; Ervin, E.; Schmidt, R. Seaweed extract, humic acid, and propiconazole improve tall fescue sod heat tolerance and posttransplant quality. HortScience 2003, 38, 440-443. [CrossRef]

38. Nikbakht, A.; Pessarakli, M.; Daneshvar-Hakimi-Maibodi, N.; Kafi, M. Perennial ryegrass growth responses to mycorrhizal infection and humic acid treatments. Agron. J. 2014, 106, 585-595. [CrossRef]

39. Daneshvar-Hakimi-Maibodi, N.; Kafi, M.; Nikbakht, A.; Rejali, F. Effect of foliar applications of humic acid on growth, visual quality, nutrients content and root parameters of perennial ryegrass (Lolium perenne L.). J. Plant Nutr. 2015, 38, 224-236. [CrossRef]

40. Zhang, X.; Schmidt, R. Antioxidant response to hormone-containing product in kentucky bluegrass subjected to drought. Crop Sci. 1999, 39, 545-551. [CrossRef]

41. Zhang, X.; Ervin, E.; Schmidt, R. Plant growth regulators can enhance the recovery of kentucky bluegrass sod from heat injury. Crop Sci. 2003, 43, 952-956. [CrossRef]

42. Ervin, E.; Zhang, X.; Roberts, J. Improving root development with foliar humic acid applications during Kentucky bluegrass sod establishment on sand. Acta Hortic. 2008, 783, 317-322. [CrossRef]

43. Zhu, H.; Li, D. Using humus on golf course fairways to alleviate soil salinity problems. HortTechnology 2018, 28, 284-288. [CrossRef]

44. Morris, K.; Shearman, R. NTEP Turfgrass Evaluation Guidelines; NTEP Turfgrass Evaluation Workshop: Beltsville, MD, USA, 1998.

45. Thoms, A.; Sorochan, J.; Brosnan, J.; Samples, T. Perennial ryegrass (Lolium perenne L.) and grooming affect bermudagrass traffic tolerance. Crop Sci. 2011, 51, 2204-2211. [CrossRef]

46. Karcher, D.; Richardson, M. Quantifying turfgrass color using digital image analysis. Crop Sci. 2003, 43, 943-951. [CrossRef]

47. Richardson, M.; Karcher, D.; Purcell, L. Quantifying turfgrass cover using digital image analysis. Crop Sci. 2001, 41, 1884-1888. [CrossRef]

48. Caturegli, L.; Gaetani, M.; Volterrani, M.; Magni, S.; Minelli, A.; Baldi, A.; Brandani, G.; Mancini, M.; Lenzi, A.; Orlandini, S.; et al Normalized Difference Vegetation Index versus Dark Green Colour Index to estimate nitrogen status on bermudagrass hybrid and tall fescue. Int. J. Remote Sens. 2020, 41, 455-470. [CrossRef]

49. Marín, J.; Yousfi, S.; Mauri, P.; Parra, L.; Lloret, J.; Masaguer, A. RGB vegetation indices, NDVI, and biomass as indicators to evaluate C3 and C4 turfgrass under different water conditions. Sustainability 2020, 12, 2160. [CrossRef]

50. Mehlich, A. Mehlich 3 soil test extractant: A modification of Mehlich 2 extractant. Commun. Soil Sci. Plant Anal. 1984, 15, 1409-1416. [CrossRef]

51. Nelson, D.; Sommers, L. Total carbon, organic carbon, and organic matter. Methods Soil Anal. Part 3 Chem. Methods 1996, 5, 961-1010.

52. Vance, E.; Brookes, P.; Jenkinson, D. An extraction method for measuring soil microbial biomass C. Soil Biol. Biochem. 1987, 19, 703-707. [CrossRef]

53. McDaniel, M.; Grandy, A.; Tiemann, L.; Weintraub, M. Crop rotation complexity regulates the decomposition of high and low quality residues. Soil Biol. Biochem. 2014, 78, 243-254. [CrossRef]

54. Joergensen, R. The fumigation-extraction method to estimate soil microbial biomass: Calibration of the kEC value. Soil Biol. Biochem. 1996, 28, 25-31. [CrossRef] 
55. Brookes, P.; Landman, A.; Pruden, G.; Jenkinson, D. Chloroform fumigation and the release of soil nitrogen: A rapid direct extraction method to measure microbial biomass nitrogen in soil. Soil Biol. Biochem. 1985, 17, 837-842. [CrossRef]

56. Grandy, A.; Robertson, G. Land-use intensity effects on soil organic carbon accumulation rates and mechanisms. Ecosystems 2007, 10, 58-73. [CrossRef]

57. De, M.; Riopel, J.; Cihacek, L.; Lawrinenko, M.; Baldwin-Kordick, R.; Hall, S.; McDaniel, M. Soil health recovery after grassland reestablishment on cropland: The effects of time and topographic position. Soil Sci. Soc. Am. J. 2020, 84, 568-586. [CrossRef]

58. Gao, Y.; Li, D. Foliar fertilization by tank-mixing with organic amendment on creeping bentgrass. HortTechnology 2012, 22, 157-163. [CrossRef]

59. Van Dyke, A.; Johnson, P.; Grossl, P. Humic substances effect on moisture retention and phosphorus uptake in intermountain west putting greens. Appl. Turfgrass Sci. 2008. [CrossRef]

60. Hunter, A.; Butler, T. The effects of humic acid, seaweed extract and PHC organic plant feed on the growth and development of Agrostis stolonifera Penn A4 grass in a sand based rootzone. Int. Turfgrass Soc. Res. J. 2005, 10, 937-943.

61. Zinati, G.; Li, Y.; Bryan, H. Utilization of compost increases organic carbon and its humin, humic and fulvic acid fractions in calcareous soil. Compos. Sci. Util. 2001, 9, 156-162. [CrossRef]

62. Liu, Y.; Dell, E.; Yao, H.; Rufty, T.; Shi, W. Microbial and soil properties in bentgrass putting greens: Impacts of nitrogen fertilization rates. Geoderma 2011, 162, 215-221. [CrossRef]

63. Prakash, N.; Dhumgond, P.; Shruthi; Ashrit, S. Performance of slag-based gypsum on maize yield and available soil nutrients over commercial gypsum under acidic and neutral soil. Commun. Soil Sci. Plant Anal. 2020, 51, 1780-1798. [CrossRef]

64. Qian, Y.; Follett, R.; Lal, R.; Augustin, B. Carbon dynamics and sequestration in urban turfgrass ecosystems. In Carbon Sequestration in Urban Ecosystems; Springer Science + Media: New York, NY, USA, 2012; pp. 161-172.

65. Albiach, R.; Canet, R.; Pomares, F.; Ingelmo, F. Microbial biomass content and enzymatic activities after the application of organic amendments to a horticultural soil. Bioresour. Technol. 2000, 75, 43-48. [CrossRef]

66. Yao, H.; Bowman, D.; Rufty, T.; Shi, W. Interactions between $\mathrm{N}$ fertilization, grass clipping addition and pH in turf ecosystems: Implications for soil enzyme activities and organic matter decomposition. Soil Biol. Biochem. 2009, 41, 1425-1432. [CrossRef]

67. Wang, Y.; Tu, C.; Li, C.; Tredway, L.; Lee, D.; Snell, M.; Zhang, X.; Hu, S. Turfgrass management duration and intensities influence soil microbial dynamics and carbon sequestration. Int. J. Agric. Biol. 2014, 16, 139-145.

68. Lu, C.; Bowman, D.; Rufty, T.; Shi, W. Reactive nitrogen in turfgrass systems: Relations to soil physical, chemical, and biological properties. J. Environ. Qual. 2015, 44, 210-218. [CrossRef] [PubMed]

69. Kerek, M.; Drijber, R.; Powers, W.; Shearman, R.; Gaussoin, R.; Streich, A. Accumulation of microbial biomass within particulate organic matter of aging golf greens. Agron. J. 2002, 94, 455-461. [CrossRef]

70. Shi, W.; Muruganandam, S.; Bowman, D. Soil microbial biomass and nitrogen dynamics in a turfgrass chronosequence: A short-term response to turfgrass clipping addition. Soil Biol. Biochem. 2006, 38, 2032-2042. [CrossRef]

71. Shi, W.; Yao, H.; Bowman, D. Soil microbial biomass, activity and nitrogen transformations in a turfgrass chronosequence. Soil Biol. Biochem. 2006, 38, 311-319. [CrossRef]

72. Shi, W.; Bowman, D.; Rufty, T. Soil microbial community composition and function in turfgrass ecosystems. Biodivers. Bioavail. 2007, 1, 72-77.

73. Treseder, K. Nitrogen additions and microbial biomass: A meta-analysis of ecosystem studies. Ecol. Lett. 2008, 11, 1111-1120. [CrossRef] [PubMed]

74. Jian, S.; Li, J.; Chen, J.; Wang, G.; Mayes, M.; Dzantor, K.; Hui, D.; Luo, Y. Soil extracellular enzyme activities, soil carbon and nitrogen storage under nitrogen fertilization: A meta-analysis. Soil Biol. Biochem. 2016, 101, 32-43. [CrossRef]

75. Moore, D.; Guillard, K.; Morris, T.; Brinton, W. Correlation between Solvita labile amino-nitrogen and $\mathrm{CO}_{2}$-burst soil health tests and response to organic fertilizer in a turfgrass soil. Commun. Soil Sci. Plant Anal. 2019, 50, 2948-2959. [CrossRef]

76. Lu, M.; Zhou, X.; Luo, Y.; Yang, Y.; Fang, C.; Chen, J.; Li, B. Minor stimulation of soil carbon storage by nitrogen addition: A meta-analysis. Agric. Ecosyst. Environ. 2011, 140, 234-244. [CrossRef]

77. Kaye, J.; McCulley, R.; Burke, I. Carbon fluxes, nitrogen cycling, and soil microbial communities in adjacent urban, native and agricultural ecosystems. Glob. Chang. Biol. 2005, 11, 575-587. [CrossRef]

78. Moore, D.; Guillard, K.; Morris, T.; Brinton, W. Predicting cool-season turfgrass response with Solvita soil tests, part 2: $\mathrm{CO}_{2}-\mathrm{burst}$ carbon concentrations. Crop Sci. 2019, 59, 2237-2248. [CrossRef]

79. Jenkinson, D.; Fox, R.; Rayner, J. Interactions between fertilizer nitrogen and soil nitrogen—the so-called 'priming' effect. J. Soil Sci. 1985, 36, 425-444. [CrossRef] 